e-ISSN: 2686-522X, p-ISSN: 2686-5211

DOI: https://doi.org/10.38035/jafm.v1i5

Received: 01 October 2020, Revised: 09 October 2020, Publish: 02 November 2020

https://creativecommons.org/licenses/by/4.0/

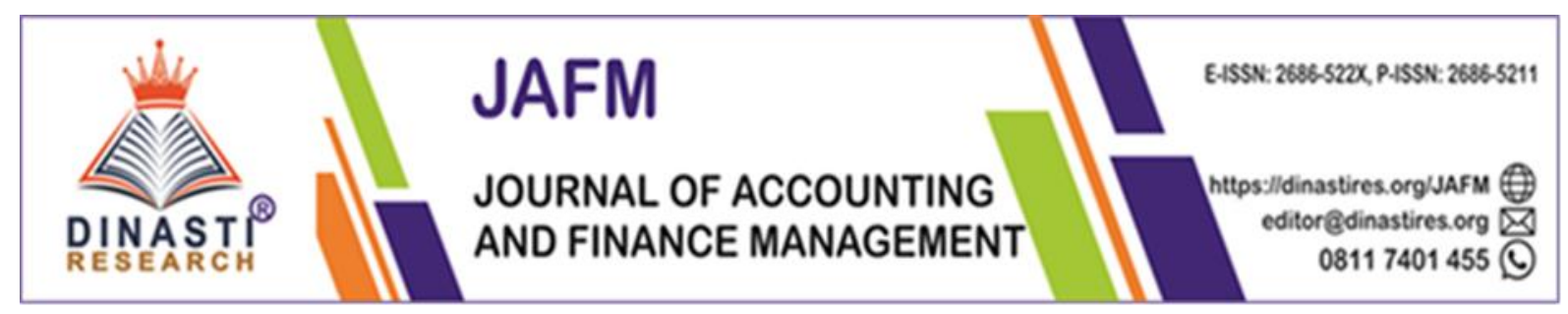

\title{
Effects of Intervening Loan to Deposit Ratio on Profitability
}

\author{
Laynita Sari $^{1)}$, Renil Septiano ${ }^{2)}$ \\ ${ }^{1)}$ STIE KBP, Padang, Indonesia, laynitasari4@gmail.com \\ ${ }^{2)}$ STIE KBP, Padang, Indonesia, renil_septiano@gmail.com
}

Corresponding Author: Laynita Sari ${ }^{1}$

\begin{abstract}
Government banks have a higher level of trust in society, as most of these shares are owned by the Government. Ratio used to assess a bank's performance is the Return on Asset ratio. Each bank will try to keep its Return on Asset ratio consistently rising and the Non Performing Loan ratio consistently falling. But the phenomenon is that the ratio of Return on Asset and Non Performing Loan at the Government Bank fluctuated from 2014 to 2019. I will therefore examine the factors that affect the ratio of Return on Assets and NonPerforming Loans to government banks. In this study, the ratios used were Non Performing Loan, Net Interest Margin, Capital Adequacy Ratio as an independent variable, Loan to Deposit Ratio as an intervening variable and Return on Asset on its dependent variables. The result that the Variable Loan to Deposit Ratio mediates the relationship between Net Interest Margin and Return on Asset.
\end{abstract}

Keywords: NPL, ROA, LDR, Government Bank

\section{INTRODUCTION}

The banking industry is an industry in the financial services sector that needs to get special attention or supervision about its performance and health in order for a country's economy to run smoothly. The purpose of supervision in the banking industry is to realize an efficient and healthy banking system (Widiarti et al, 2015). This important role keeps the wheels of a country's economy running because banks bring together those who have more funds with those who need funds. The definition of bank according to Article 2 of Law No. 10 of 1998 in banking is a business entity that collects funds from the public in the form of deposits and distributes them to the public to improve the living standards of the people.

Financial development or performance of a bank from its profitability performance. According to Bank Indonesia, the important profitability ratio for banks is Return On Asset (ROA) (Latifah et al, 2012). According to (Astohar, 2016) Return On Asset (ROA) is used to measure bank profitability. This is also in line with the direction of Bank Indonesia as a 
banking supervisor and supervisor is under the auspices of the Financial Services Authority (OJK) prioritizing the profitability value of banks. The greater return on asset (ROA) can be said to be the higher the level of profit achieved by the bank, which is the optimal position of the bank in terms of the use of assets.

In Indonesia there are four Government Banks namely Bank Rakyat Indonesia, Bank Negara Indonesia, Bank Mandiri, and Bank Tabungan Negara. This Government Bank is a bank whose shares are majority controlled by the Government of Indonesia. Therefore, Government banks are more trusted by the public to save and for loans. The Government Bank will also try to keep the ROA up.

Table 1. Average Financial Ratios of Government Banks

\begin{tabular}{|c|c|c|c|c|c|}
\hline \multirow{2}{*}{ YEAR } & \multicolumn{5}{|c|}{ RATIO (\%) } \\
\cline { 2 - 6 } & ROA & NPL & NIM & CAR & LDR \\
\hline 2014 & 3,19 & 2,45 & 6,31 & 16,44 & 90,30 \\
\hline 2015 & 2,86 & 2,69 & 6,33 & 18,91 & 92,78 \\
\hline 2016 & 2,56 & 2,95 & 6,36 & 20,99 & 91,68 \\
\hline 2017 & 2,72 & 2,62 & 5,96 & 20,50 & 91,24 \\
\hline 2018 & 2,74 & 2,42 & 5,65 & 19,72 & 94,49 \\
\hline 2019 & 2,27 & 3,02 & 5,17 & 20,25 & 97,51 \\
\hline
\end{tabular}

Source: Financial Statements from each Government Bank

From the table above explains the changes in ROA, NPL, NIM, CAR and LDR of Government Banks during the period 2014 to 2019. There is an inconsistent relationship between ROA variables, NPL variables, NIM variables, CAR variables or LDR variables. The desired ROA ratio always rises, but in fact from 2014 to 2019 the financial ratio of ROA of the Government Bank is volatile. The phenomenon that occurred from 2014 to 2016 is that the ROA ratio of government banks always decreased, where in $20143.19 \%$ decreased by $0.33 \%$ in 2015, so the ratio of ROA in 2015 to $2.86 \%$. In 2016 the ROA ratio decreased again from $0.3 \%$ in 2015 to $2.56 \%$. In 2017 the ROA ratio increased by $0.16 \%$ from 2016 so the ROA ratio to $2.72 \%$, in 2018 the ROA ratio also increased by $0.02 \%$ from 2017 to $2.74 \%$. But in 2019 the ROA ratio decreased by $0.47 \%$ so that the ROA ratio increased by $2.27 \%$. During 2014 to 2019, this was the largest decrease in ROA ratios.

No less important in maintaining the bank's performance to grow properly, one of the financial ratios of concern is the Non Performing Loan (NPL) ratio. Banks should keep this NPL ratio always down, because if it allows this ratio to increase it will affect the decline in profits, and eventually the bank's performance will fall. After observing the Government Bank's NPL ratio from 2014 to 2019, there is a phenomenon where from 2014 to 2016 the NPL ratio always increases, where in 2014 it increased by $2.45 \%$ by $0.23 \%$ in 2015 so the NPL ratio to $2.69 \%$. In 2016, the NPL ratio increased by $0.26 \%$ from 2015 to $2.95 \%$. In 2017, the NPL ratio decreased by $0.33 \%$ from 2016 to $2.62 \%$. In 2018 the NPL ratio also decreased by $0.20 \%$ from 2017 to $2.42 \%$. But in 2019 the NPL ratio increased by $0.60 \%$ to $3.02 \%$. During 2014-2019 the largest increase in NPL ratio occurred in 2019.

In examining the ratio of ROA and NPL there is a research gap in previous research conducted by (Prihartini, Dana, 2018) where research was conducted at Bank Rakyat Indonesia, resulting in that the direct influence of NPL on ROA distribution is negative and significant. This means that the larger the non-performing loans, the more revenue reflected 
through the ROA will also be reduced. Meanwhile, research conducted by (Muliawati, Khoiruddin, 2015) which examined sharia banks resulted in a partial NPF positive effect on ROA showed by a regression coefficient of 0.571 and a significance rate of over 0.05 which is 0.571 . Research on NPL and ROA ratios has also been conducted by (Sari, Tanno, Putri, 2019) where the ratio of NPL as a moderation variable results in that the NPL Variable is not a moderation between LDR and ROA, so it can be concluded that the NPL variable is not a moderating variable.

Besides the NPL and ROA ratios, the ratio that is no less important in banking is the Net Interest Magin ratio. Net Interest Margin is the ratio used to analyze how much net interest income compares to the company's productive assets. In table 1 above we can see that the ratio of NIM to state-owned banks from 2014 to 2016 always rises, and from 2017 to 2019 the NIM ratio of government banks always falls. We can see that from 2014 to 2015 the NIM ratio increased by $0.02 \%$ to $6.33 \%$ in 2015. In 2016, the NIM ratio also increased by $0.03 \%$ from 2015 to $6.36 \%$. In 2017 there was a decrease in NIM by $0.41 \%$ from 2016 to NIM in 2017 to 5.96\%. In 2018 NIM again decreased by $0.31 \%$ from 2017 so that in 2018 the NIM ratio to 5.65\%. During 2014 to 2019, the most NIM decrease occurred in 2019, where NIM decreased by $0.48 \%$ from 2018 to NIM in 2019 by $5.17 \%$. Research by (Arsyad, 2019) which conducted research on banks in Egypt found that NIM had a significant positive effect on profitability. While the results of the study by (Pedro and M.Yunanto, 2018) showed results that NIM had no significant positive effect on ROA. Other research conducted by (Harun, 2016) states that NIM has no effect on ROA.

Capital Adequacy Ratio (CAR) is a bank performance ratio to measure the adequacy of capital held by banks to support assets that contain or generate risk, such as loans provided. CAR shows the extent to which the decline in bank assets that can still be closed by equity banks available, the higher CAR than the better the condition of the bank. The larger the Capital Adequacy Ratio (CAR) then the bank's profits will also be greater. Government Banks, the average ratio from 2014 to 2019 is volatile. In 2014, car ratio of $16.44 \%$ increased by $2.47 \%$ in 2015 to $92.78 \%$. In 2016, car ratio of $91.68 \%$ decreased by $1.10 \%$ from 2015 . In 2017 , car ratio of $91.24 \%$ decreased by $0.44 \%$ from 2016 . In 2018 , car ratio amounted to $94.49 \%$ up by $3.25 \%$ from 2017. In 2019, car ratio of $97.51 \%$ increased by $3.03 \%$ from 2018 . Previous research on CAR to ROA conducted (Edwar, Bernardin, 2016) CAR had a significant influence on ROA. Meanwhile, research conducted (Putrianingsih, Yulianto, 2016) on banking companies in IDX concluded that the Capital Adequacy Ratio (CAR) had no effect on Return On Asset (ROA) in banking companies.

The Loan to Deposit Ratio (LDR) shows a bank's ability to provide funds to its debtors with capital held by banks and funds the public can collect that. From 2014 to 2019 the Government Bank's LDR ratio was volatile. In 2014 the average was $90.30 \%$ up by $2.47 \%$ in 2015 to $92.78 \%$. In 2016 the average Government Bank LDR ratio was $91.68 \%$, down by $1.10 \%$ from 2015. In 2017, the LDR ratio of $91.24 \%$ decreased by $-0.44 \%$ from 2016 . In 2018 the LDR ratio of $94.49 \%$ increased by $3.25 \%$ in 2017. And in 2019 the LDR value of $97.51 \%$ increased by $3.03 \%$ from 2018. A previous study that looked at LDR's relationship to ROA was conducted by (Sari, Tanno, Putri, 2019) at state-owned banks concluded that LDR had a significant negative effect on ROA. Other research also conducted by (Pertiwi, 
2014) at the National Private Public Bank of Foreign Exchange on the Indonesia Stock Exchange resulted in that LDR had a negative and significant effect on Return On Asset.

From the phenomenon in the ratio of ROA, NPL, NIM, CAR and LDR at the Government Bank described above and there is a research gap in the previous research, then this research issue concerning banking performance is proxy'd with ROA. This research aims to conduct empirical studies on the factors that influence changes in ROA that impact the banking performance of the Government Bank. Some previous studies have examined using the same variables, then several factors that will be tested affect the ROA namely the calculation of NPL, NIM, CAR and LDR ratios as intervening variables in government banks.

\section{LITERATURE REVIEW Bank}

The understanding of the Bank based on Law No. 10 of 1998 on banking that perfected Law No. 7 of 1992 on banking, is: "Bank is a business entity that raises funds from the community in the form of deposits and distributes it to the public in the form of credit and or other forms to improve the living standards of many people". So banks are business entities whose business activities raise funds from the community in the form of deposits and channel them back to the community in the form of credit and or in other forms and providing other bank services to improve the living standards of many people.

The Bank is a financial institution whose primary activity is to raise funds from the community and re-channel the funds to the community and provide other Bank services (Cashmere, 2016).

\section{Government Bank}

Regulates the Government Bank in Law No. 19 of 2003 on State-Owned Enterprise (referred to as the SOE Law). This law gives the understanding of so-called SOEs themselves. In Article 1 number 1 of the SOE Law states that SOEs are business entities that all or most of the capital is owned by the state through direct participation derived from the wealth of a segregated country.

\section{Bank Financial Performance}

The performance of the company as a formal business carried out by the company to test the efficient and effectiveness of the company's activities that have been carried out in a certain period. Financial performance is the determination of certain measures that can measure the success of an organization or company in generating profit (Sucipto, 2003).

An assessment of a bank's performance can be done by analyzing financial statements. Financial statements comprising balance sheets will inform outside banks, such as the Central Bank, the public, and external parties can also use investors about the picture of its financial position to assess the amount of risk that exists in a bank. Other financial statements namely profit or loss summarize the development of the bank's business. The financial statements also show the Bank's performance.

\section{ROA (Return On Asset)}

In this study, banking performance was measured by ROA, where ROA measures the bank's management's ability to manage its assets for overall profit (Dendawijaya, 2003). The larger the ROA of a bank, the greater the level of profit achieved by the bank and the better it 
is an important indicator of the ratio for shareholders and potential investors to measure the Bank's ability to get net income associated with dividend payments.

According to SE BI No. 13/24/DPNP dated October 25, 2011, the ROA standard set for banks in Indonesia is at least $1.5 \%$. Formula for calculating Return On Asset (ROA):

$$
\text { ROA }=\frac{\text { Profit Before Tax }}{\text { Average Total Assets }} \times 100 \%
$$

\section{Non Performing Loan (NPL)}

Non Performing Loan (NPL) is a key indicator in assessing the bank's function performance, high NPL value can to be an overview of the bank's failure to manage the business causing liquidity problems (inability to pay third parties), Rentability (non-billable debt), Solvency (Reduced capital). Meanwhile, falling profits are one consequence because practical banks lose sources of income besides having to set aside reserves according to credit collectibility.

According to SE BI No. 13/24/DPNP dated October 25, 2011 Credit risk is the risk because of the failure of the debtor and or any other party in fulfilling obligations to the bank. A healthy Non Performing Loan (NPL) standard of the non-performing loan amount is not over $5 \%$ of the total credit given to the debtor. If it exceeds $5 \%$, it will affect the bank's health level. Formula for calculating Non Performing Loan (NPL) :

$$
N P L=\frac{\text { Non Performing Loans }}{\text { Total Credits Issued }} \times 100 \%
$$

The NPL describes the level of non-performing loans held by a bank. The bigger the NPL, the worse the credit quality of the bank will lead to losses and the lower the LDR. (Sukma, 2013) showed results that NPL had a negative and significant effect on LDR. According to (Raditya, Ritha, 2013) the higher NPL will encourage a decrease in the number of loans channeled because of the greater number of non-performing loans resulting in the bank having to bear losses in its operational activities, thus affecting the lack of intermediation function carried out by the bank. (Buchory, 2014) proves that the Non Performing Loan (NPL) ratio negatively affects the Loan to Deposit Ratio (LDR). Then researchers can lower the hypothesis:

\section{H1 : NPL has a significant negative effect on LDR}

In previous research on the ratio of NPL and ROA conducted by (Prihartini, Dana, 2018) where research on Bank Rakyat Indonesia, resulted in that the direct influence of NPL on ROA distribution was negative and significant. This means that the larger the nonperforming loans, the more revenue reflected through the ROA will also be reduced. Similar research was also conducted by (Zuspita, Yadnya, 2019) research conducted on public banks on the Indonesia Stock Exchange, stating that NPL had a significant negative effect on ROA on commercial banks in idX for the period 2013-2015. The results the implication that bank management should have wonderful ability in credit assessment, assessment of guarantees and monitoring of debtors, thus allowing banks to avoid the buildup of bad loans that can later affect the bank's ROA on loan interest paid by debtors. Other research also conducted by (Peling, Sedana, 2018) at BPD Bali bank for the period 2009-2016 resulted in that NPL 
had a negative and significant effect on ROA on PT. Bank Pembangunan Daerah Bali period 2009 - 2016. This means that the higher the risk of credit, the lower the income received by PT. Bali Regional Development Bank. Then researchers can lower the hypothesis:

\section{H4 : NPL has a significant negative effect on ROA}

H8 : NPL has a significant negative effect on ROA mediated by LDR

\section{Net Interest Margin (NIM)}

Net Interest Margin (NIM) is a comparison between net interest income to average productive assets. This ratio shows the ability of banks to generate net interest income with placing productive assets. The greater this ratio, the better the bank's performance in generating interest in income. But must ensure it that this is not because of high intermediation costs, assuming interest income should be re-invested to strengthen the bank's capital (Taswan, 2010).

According to SE BI No. 13/24/DPNP dated October 25, 2011, the NIM standard stipulated for banks in Indonesia is at least 3\%. Formula for calculating Net Interest Margin (NIM) :

$$
N I M=\frac{\text { Net Interest Income }}{\text { Average Productive Assets }} \times 100 \%
$$

Previous research on Net Interest Margin to Loan to Deposit Ratio (Prayudi, 2016), (Agustina, Wijaya, 2013), (Buchory, 2014), (Saraswati, 2012), (Amriani, 2012), and (Granita, 2012) NIM had a positive and significant effect on LDR. Then researchers can lower the hypothesis:

\section{H2 : NIM has a positive and significant effect on LDR}

In previous research, on the ratio of Net Interest Margin to Return On Asset conducted by (Arsyad, 2019) conducted research of banks in Egypt found that NIM had a significant positive effect on profitability. Similar research conducted by (Sugiantari, Dana, 2019) found that Net Interest Margin had a positive and significant effect on ROA. Other research also conducted by (Grace, Yatna, 2019) on conventional public banks book four shows Net Interest Margin (NIM) has a positive and significant effect on profitability proxies by Return On Asset at Conventional Commercial Bank BUKU 4. Then researchers can lower the hypothesis:

\section{H5 : NIM has a significant positive effect on ROA \\ H9 : NIM has a significant positive effect on ROA mediated by LDR}

\section{Capital Adequacy Ratio (CAR)}

Capital Adequacy Ratio (CAR) is a ratio that shows how far all bank assets containing risk (credit, inclusion, securities, bills at other banks) are financed from the bank's own capital funds, besides obtaining funds from sources outside the bank, such as public funds, loans (debt), and others (Dendawijaya, 2009). Bank Indonesia requires that each commercial bank provide a minimum capital of $8 \%$ of its total risk-weighted assets (ATMR).

Based on SE BI No.13/24/DPNP dated October 25, 2011, capital factor assessment includes an assessment of capital adequacy level and an assessment of bank capital management. Capital factors using the Capital Adequacy Ratio (CAR). Capital Adequacy Ratio (CAR) formula : 


\section{CAR $=\frac{\text { Capital }}{\text { Risk Weighted Assets }} \times 100 \%$}

Previous research on capital adequacy ratio to loan to deposit ratio (Nandadipa, 2010) Banks that have high CAR then credit is also a lot, so if CAR increases it will increase LDR. Research conducted by Prayudi (2011), Hersugondo \& Tamtomo (2012) resulted in that CAR had a positive and significant effect on LDR. Then (Granita, 2012) concluded that CAR had a positive and significant effect on LDR. Then researchers can lower the hypothesis:

\section{H3 : CAR has a significant positive effect on LDR}

Previous research on capital adequacy ratio to return on assets (Muhamad, 2015) stated that if the greater the Capital Adequacy Ratio (CAR) then the profitability got by banks will be even greater. Because the larger the Capital Adequacy Ratio (CAR) the higher the bank's capital in maintaining the possibility of loss risk in its business activities. Hypotheses about CAR's influence on profitability are supported (Margaretha, Zai, 2013), (Ongore, Kusa, 2013) and (Christiano et al., 2014) which reveal that CAR has a positive effect on ROA. Then researchers can lower the hypothesis:

\section{H6 : CAR has a significant positive effect on ROA}

\section{H10 : CAR has a significant positive effect on ROA mediated by LDR}

\section{Loan to Deposit Ratio (LDR)}

LDR is a ratio that describes the comparison between a credit issued by a bank and the total third party funds collected by a bank (Cashmere, 2014). This ratio will show the level of the bank's ability to channel third party funds raised by the relevant bank. Based on Bank Indonesia No. 15/7PBI/2013 dated October 1, 2013, the LDR figure should be around 78\% $100 \%$.

$$
L D R=\frac{\text { Banks Total Loans }}{\text { Total Deposits }} \times 100 \%
$$

The small size of a bank's LDR ratio will affect the bank's profitability. The higher the LDR owned by a bank shows also that the ability of banks to earn profit is better, anyway. Previous research conducted by Hypothesis on the influence of LDR on profitability was supported by the results of margaretha and zai research (2013) and Christiano et al., (2014) which revealed that LDR had a significant positive effect on ROA. Based on the description, the hypothesis:

\section{H7 : LDR has a significant positive effect on ROA}

\section{RESEARCH METHODS}

\section{Research Sites}

This research at the Government Bank through financial report data for the period 2014-2019. Through financial statements owned by the Government Bank, researchers processed the data according to the variables used in the study, both for independent variables, mediation variables, and dependent variables. Thus the data processed by the researchers is quantitative data. The financial statements used from each official website of BANK BRI, Bank BNI, Bank Mandiri, and Bank BTN. 
Quantitative research includes relatively extensive libraries to give direction to research questions or hypotheses. In planning quantitative research, library studies are often used to usher in a problem in the introduction, (Ali \& Limakrisna, 2013).

\section{Research Design}

This research wants to find out how independent variables such as Non Performing Loan (NPL) affect dependent variables, namely Return on Assets (ROA) of Government Banks through Net Interest Margin (NIM) as intervening variables. This research used data in the form of semester financial statements owned by the Government Bank in the period 20142019. This financial report data from each official website of BANK BRI, Bank BNI, Bank Mandiri, and Bank BTN.

\section{Data Collection Methods}

The method of collecting data in this study is to collect data from the semester financial statements of the Government Bank from the period 2014 to 2019. This financial report data from each official website of BANK BRI, Bank BNI, Bank Mandiri, and Bank BTN.

\section{Types and Data Sources}

The data used in this study is secondary data is already in the form of reports, already recorded and trusted. While the data source in this study comes from the official website of the Government Bank in the form of semester financial statements belonging to Bank BRI, Bank BNI, Bank Mandiri and Bank BTN from 2014 to 2019.

\section{Data Analysis}

Based on the conceptual framework, the data analysis used in this study is path analysis. Path analysis is when independent variables can directly or indirectly affect dependent variables. Indirect effect here means that there are intervening variables that mediate the influence of independent variables on dependent variables.

Path analysis is a multivariate data analysis method to know the direct and indirect influence of multiple causal variables (exogenous) on endogenous variables (consequences) with recursive patterns, and all variables can be observed directly. Recursive means that the relationship between variables is one-way, there is no reciprocal relationship. If stated A cause B, then B cannot cause A, (Ali \& Limakrisna, 2013).

\section{FINDINGS AND DISCUSSION}

The hypothetical test results of model 1 influence of NIM, NPL, CAR on LDR :

\begin{tabular}{ccccccc}
\hline \multicolumn{7}{c}{ Table 2 Effect of NIM, NPL, CAR on LDR } \\
\hline \multicolumn{7}{c}{ Unstandardized Coefficients } \\
\hline Model & & B & Std. Error & Beta & t & Sig. \\
\hline 1 & (Constant) & 100.962 & 11.005 & & 9.174 & .000 \\
\hline NIM & -3.223 & .989 & -.464 & -3.260 & .002 \\
\hline NPL & 3.890 & 1.562 & .323 & 2.491 & .017 \\
\hline CAR & .072 & .510 & .018 & .141 & .889 \\
\hline a.Dependent Variable: LDR & & & & &
\end{tabular}

SPSS test results regression equations:

$\mathrm{LDR}=100,962-3,223 \mathrm{NIM}+3,890 \mathrm{NPL}+$ 0,072 CAR

Hypothetical test results of model 2 influence of NIM, NPL, CAR, LDR on ROA : 
Table 3 Effect of NIM, NPL, CAR, LDR on ROA

\begin{tabular}{ccccccc}
\hline \multicolumn{7}{c}{ Unstandardized Coefficients } \\
\hline Model & & B & Std. Error & Beta & t & Sig. \\
\hline 1 & (Constant) & 2.913 & 1.112 & & 2.620 & .012 \\
\hline NIM & .418 & .065 & .573 & 6.450 & .000 \\
\hline NPL & -.436 & .098 & -.343 & -4.439 & .000 \\
\hline CAR & .001 & .030 & .002 & .024 & .981 \\
\hline LDR & -.016 & .009 & -.155 & -1.823 & .075 \\
\hline a. Dependent Variable: ROA & & & & & \\
\hline
\end{tabular}

SPSS test results regression equations:

$\mathrm{ROA}=2,913+0,418 \mathrm{NIM}-0,436 \mathrm{NPL}+0,001 \mathrm{CAR}-0,016 \mathrm{LDR}$

\section{The test results of each variable:}

\section{NPL variable to $L D R$}

H1 : NPL has a significant negative effect on LDR

The results of the NPL influence test on LDR got a t value of 2,491 significance of 0.017 . A value of significance smaller than 0.05 shows that NPL has a significant positive effect on LDR. This means it rejects Hypothesis 1.

\section{NIM variables to LDR}

$\mathrm{H} 2$ : NIM has a positive and significant effect on LDR

NIM influence test results on LDR got a t value of $-3,260$ significance of 0.002 . A value of significance smaller than 0.05 shows that NIM has a significant negative effect on LDR. This means Hypothesis 2 rejected.

\section{CAR variables to $L D R$}

H3 : CAR has a significant positive effect on LDR

The results of the car influence test on LDR a t value of 0.141 significance of 0.889 . A value of significance greater than 0.05 shows that CAR has an insignificant positive effect on LDR. This means Hypothesis 3 rejected.

\section{NPL variables to ROA}

H4 : NPL has a significant negative effect on ROA

The results of the NPL influence test on ROA got a t value of $-4,439$ significance of 0.000 . A value of significance smaller than 0.05 shows that NPL has a significant negative effect on ROA. This means Hypothesis 4 accepted.

\section{NIM variables to ROA}

H5 : NIM has a significant positive effect on ROA

The results of the NIM influence test on ROA a t value of 6,450 significance of 0.000 . A value of significance smaller than 0.05 shows that NIM has a significant positive effect on ROA. This means Hypothesis 5 accepted.

\section{CAR variables to ROA}

H6 : CAR has a significant positive effect on ROA

The results of the car influence test on ROA a $t$ value of 0.024 significance of 0.981 . A value of significance greater than 0.05 shows that CAR has an insignificant positive effect on ROA. This means Hypothesis 6 rejected. 


\section{LDR variables to ROA}

H7 : LDR has a significant positive effect on ROA

The results of the LDR influence test on ROA a t value of $-1,823$ significance of 0.075 . A value of significance greater than 0.05 shows that LDR has an insignificant negative effect on ROA. This means Hypothesis 7 rejected.

Intervening Test Results for hypothesis 8, 9, and 10, then we must first determine the value of the detergent coefficient $\left(\mathrm{R}^{2}\right)$.

$\mathrm{R}$ square value of the regression in the following table:

Table 4. R Square CAR, NPL, NIM Values

\begin{tabular}{ccccc}
\hline Model & $\mathbf{R}$ & $\begin{array}{c}\mathbf{R} \\
\text { Square }\end{array}$ & $\begin{array}{c}\text { Adjusted R } \\
\text { Square }\end{array}$ & $\begin{array}{c}\text { Std. Error of the } \\
\text { Estimate }\end{array}$ \\
\hline 1 & $.678 \mathrm{a}$ & .459 & .422 & 6.94489 \\
\hline a. Predictors: (Constant), CAR, NPL, NIM & \\
\hline
\end{tabular}

Table 4 above we can see that the value of $\mathrm{R}$ square is 0.459 . This means that $45.9 \%$ of LDR affected by CAR, NPL, NIM, other variables affect the remaining $54.1 \%$. e1 $=\sqrt{ }(1-0,459)=0,736$

Table 5 R Square LDR, CAR, NPL, NIM Values

\begin{tabular}{|c|c|c|c|c|}
\hline Model & $\mathbf{R}$ & $\begin{array}{c}\mathbf{R} \\
\text { Square }\end{array}$ & Adjusted R Square & Std. Error of the Estimate \\
\hline 1 & $.914 \mathrm{a}$ & .835 & .820 & .40807 \\
\hline
\end{tabular}

a. Predictors: (Constant), LDR, CAR, NPL, NIM

Table 5 above we can see that the $\mathrm{R}$ square value is 0.835 , this means that $83.5 \%$ of ROA affected by LDR, CAR, NPL, NIM, other variables affect the remaining $16.5 \%$. e2 $=\sqrt{ }(1-0,835)=0,406$

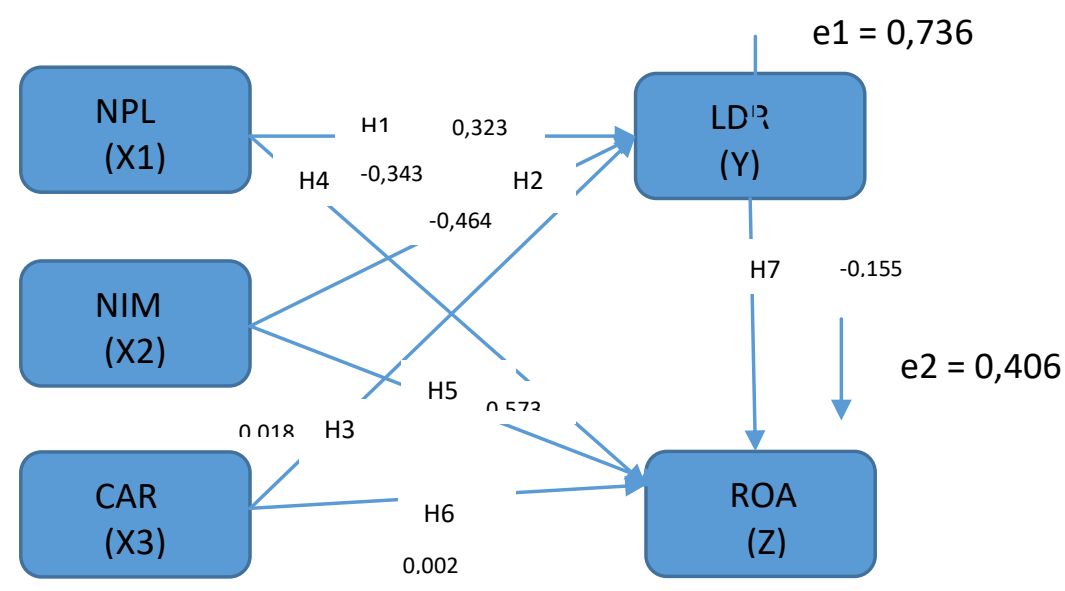

\section{NPL variables to ROA mediated LDR}

H8 : NPL has a significant negative effect on ROA mediated LDR

$\mathrm{X} 1 \rightarrow \mathrm{Z}=-0,343$

$\mathrm{X} 1$ mediated $\mathrm{Y}$ to $\mathrm{Z}=0,323 \times-0,155=-0,050$

Total influence exerted X1 $\rightarrow Z=-0,343-0,050=-0,393$ 
From the calculation, the direct influence $>$ indirect influence, $-0.343>-0.393$. This means that LDR does not exert influence between NPL and ROA on government banks.

Hypothesis 8 rejected.

\section{NIM variables to ROA mediated LDR}

H9 : NIM has a significant positive effect on ROA mediated by LDR

$\mathrm{X} 2 \rightarrow \mathrm{Z}=0,573$

$\mathrm{X} 2$ mediated $\mathrm{Y}$ to $\mathrm{Z}=-0,464 \mathrm{x}-0,155=0,072$

Total influence exerted $X \rightarrow Z=0,573+0,072=0,645$

From the calculation, the direct influence $<$ indirect influence, $0.573<0.645$. This means that LDR exerts influence between NIM and ROA on government banks.

Hypothesis 9 accepted.

10. CAR variables to ROA via $L D R$

H10 : CAR has a significant positive effect on ROA mediated by LDR

$\mathrm{X} 3 \rightarrow \mathrm{Z}=0,002$

$\mathrm{X} 3$ mediated $\mathrm{Y}$ to $\mathrm{Z}=0,018 \times-0,155=-0,003$

Total influence exerted X3 $\rightarrow Z=0,002-0,003=-0,001$

From the calculation, the direct influence > indirect influence, $0.002>-0.001$. This means that LDR does not exert influence between CAR and ROA on government banks. Hypothesis 10 rejected.

\section{CONCLUSION AND SUGESTION}

\section{Conclusion}

1. NPL on the Government Bank has a significant positive effect on LDR. The test result was a $t$ value of 2,491 significance of 0.017 . This means that the more non-performing loans the LDR ratio will rise.

2. NIM on the Government Bank has a significant negative effect on LDR. The test result was a $t$ value of $-3,260$ significance of 0.002 . This means that the higher the interest income at the Government Bank, the lower the LDR ratio.

3. CAR on the Government Bank has an insignificant positive effect on LDR. The test result was a t value of 0.141 significance of 0.889 . This means that the higher the capital at the Government Bank, the insignificant the LDR ratio will also rise.

4. The NPL at the Government Bank has a significant negative effect on the ROA. The test result was a $t$ value of $-4,439$ significance of 0.000 . This means that the more nonperforming loans in the Government Bank, the profit will decrease.

5. NIM at the Government Bank has a significant positive effect on the ROA. The test result was a $t$ value of 6,450 significance of 0.000 . This means that the higher the interest income at the Government Bank, the higher the profit will increase.

6. CAR at the Government Bank has an insignificant positive effect on the ROA. The test result was a t value of 0.024 significance of 0.981 . This means that as high as the capital in government banks, insignificant, the profit will also increase.

7. LDR at the Government Bank has an insignificant negative effect on the ROA. The test result was a $t$ value of $-1,823$ significance of 0.075 . This means the higher the Government Bank's LDR ratio, insignificant the profit will fall. 
8. LDR does not mediate between NPL and ROA at Government Bank. The results of calculations and comparisons between direct and indirect influences. The direct influence is between NPL on ROA and indirect influence that is NPL on ROA through LDR. The result that the direct influence $>$ of indirect influence, $-0.343>-0.393$. LDR ratio at the Government Bank has no effect on bad loans and profits.

9. LDR mediates between NIM and ROA at the Government Bank. The results of calculations and comparisons between direct and indirect influences. The direct influence is between NIM on ROA and indirect influence of NIM on ROA through LDR. The result that the direct influence $<$ indirect influence, $0.573<0.645$. LDR ratio of the Government Bank affects interest income and profit.

10. LDR does not mediate between CAR and ROA at Government Bank. The results of calculations and comparisons between direct and indirect influences. The direct influence is between CAR to ROA and the indirect influence that is CAR on ROA through LDR. The direct influence > indirect influence, where $0.002>-0.001$. LDR ratio of the Government Bank has no effect on capital and profit.

\section{Sugestion}

1. The Government Bank to keep its NPL ratio consistently down, because if this NPL grows it will erode the company's profit, and affect the company's performance.

2. The Government Bank to increase its ROA ratio and be able to maintain a consistent ratio to always rise.

3. NIM ratio has a positive effect on ROA, so that the Government Bank can optimize this ratio to continue to grow by not ruling out the principle of prudence.

4. Government banks should also maintain the stability of their LDR ratios, as this ratio can mediate the relationship between NIM and ROA.

\section{REFERENCE}

Agustina, A. J. J. W. E. M. J. (2013). Analisis Faktor-Faktor yang Mempengaruhi Loan Deposit Ratio Bank Swasta Nasional di Bank Indonesia. 3(2), 101-109.

Ali, H., \& Limakrisna, N. (2013). Research Methodology, Practical Guide to Solving Business Problems. In: Preparation of Theses and Dissertations.

Ali, H., \& Limakrisna, N. J. D. Y. (2013). Metodologi Penelitian (Petunjuk Praktis untuk Pemecahan Masalah Bisnis, Penyusunan Skripsi, Tesis, dan Disertasi).

Anugrah, T., \& Yatna, C. N. J. P. R. (2020). Pengaruh Non Performing Loan, Loan to Deposit Ratio, Net Interest Margin, Biaya Operasional Pendapatan Operasional dan Capital Adequacy Ratio Terhadap Profitabilitas Bank Umum Konvensional Buku 4 Periode 2012-2016. 4(1).

Brock, P. L., \& Suarez, L. R. J. J. o. d. E. (2000). Understanding the behavior of bank spreads in Latin America. 63(1), 113-134.

Buchory, H. A. J. I. J. o. B., Economics, \& Law. (2014). Analysis of The Effect of Capital, Credit Risk and Profitability to Implementation Banking Intermediation Function (Study on Regional Development Bank All Over Indonesia year 2012). 4(1), 133-144.

Christiano, M., Tommy, P., \& Saerang, I. J. J. E. J. R. E., Manajemen, Bisnis dan Akuntansi. (2015). Analisis Terhadap Rasio-Rasio Keuangan Untuk Mengukur Profitabilitas Pada Bank-Bank Swasta Yang Go Public Di Bursa Efek Indonesia. 2(4).

Dendawijaya, L. J. G. I. J. S. (2003). Manajemen Perbankan Cetakan Kedua. 
Edo, D. S. R., \& Wiagustini, N. L. P. J. E.-J. E. d. B. U. U. (2014). Pengaruh Dana Pihak Ketiga, Non Performing Loan, dan Capital Adequacy Ratio Terhadap Loan To Deposit Ratio dan Return On Assets Pada Sektor Perbankan Di Bursa Efek Indonesia. 3(11), 650-673.

Granita, J. K., \& Muharam, H. (2011). Analisis Pengaruh DPK, CAR, ROA, NPL, NIM, BOPO, Suku Bunga, Inflasi, dan Kurs terhadap LDR (Studi Pada Bank Umum Swasta Nasional Devisa Periode 2002-2009). Universitas Diponegoro,

Harun, U. J. J. R. B. d. M. (2016). Pengaruh Ratio-ratio Keuangan Car, Ldr, Nim, Bopo, Npl Terhadap Roa. 4(1), 67-82.

Indonesia. (1992). Undang-Undang nomor 7, tahun 1992 tentang perbankan: Mini Jaya Abadi.

Kasmir, S. (2018). Bank dan Lembaga Keuangan Lainnya Edisi Revisi.

Latifah, N. M., Rodhiyah, R., \& Saryadi, S. J. J. I. A. B. (2012). Pengaruh Capital Adequacy Ratio (Car), Non Performing Loan (Npl) Dan Loan to Deposit Ratio (Ldr) Terhadap Return on Asset (Roa)(Studi Kasus Pada Bank Umum Swasta Nasional Devisa Go Public Di Bursa Efek Indonesia Periode 2009-2010). 1(2), 57-66.

Margaretha, F. J. J. M. (2017). Faktor-Faktor yang Mempegaruhi Kinerja Keuangan Perbankan di Indonesia. 6(2).

Muhamad, N. K. J. J. E. (2015). Pengaruh CAR, NPL, DAN BOPO terhadap Profitabilitas dan Return Saham pada Bank-bank yang terdaftar di BEI tahun 2009-2013. 3(2), 258269.

Muliawati, S. (2015). Faktor-faktor penentu profitabilitas bank syariah di Indonesia. Universitas Negeri Semarang,

No, S. E. B. I. J. P. P. T. K. b. U. J. B. I. 13/24/DPNP tanggal 25 Oktober 2011.

No, U.-u. tahun 2003 tentang Badan Usaha Milik Negara (BUMN).

Nomor, U.-U. tahun 1998 tentang Perbankan. In: Jakarta: Harvarindo.

Ongore, V. O., Kusa, G. B. J. I. j. o. e., \& issues, f. (2013). Determinants of financial performance of commercial banks in Kenya. 3(1), 237.

Peling, I. A. A., \& Sedana, I. B. P. J. E.-J. M. U. U. (2018). Pengaruh LDR, NPL, dan BOPO terhadap profitabilitas pada PT. BPD Bali periode tahun 2009-2016. 7(6).

Prayudi, A. J. J. L. P. (2011). Pengaruh Capital Adequacy Ratio (CAR), Non Performing Loan (NPL), BOPO, Return On Asset (ROA) dan Net Interest Margin (NIM) terhadap Loan to Deposit Ratio (LDR).

Prihartini, S., \& Dana, I. M. J. E.-J. M. U. U. (2018). Pengaruh Car, Npl, dan Roa terhadap Penyaluran Kredit USAha Rakyat (Studi Kasus pada PT Bank Rakyat Indonesia Tbk). 7(3).

Ritha, H., \& Raditiya, E. (2014). Pengaruh Faktor Internal Dan Eksternal Terhadap Fungsi Intermediasi Pada Bank Umum Swasta Nasional (BUSN) Devisa Periode 2006-2010.

Saraswati, C. D., \& Syaichu, M. (2014). Analisis Pengaruh Car, Npl, Nim Dan Bopo Terhadap Ldr Pada Bank Umum Yang Go Public Di Indonesia Periode 2007-2013 (Studi Pada Perusahaan Perbankan Yang Terdaftar Di Bursa Efek Indonesia). Fakultas Ekonomika dan Bisnis,

Sari, L., Tanno, A., \& Putri, A. J. J. I. A. B. d. I. (2020). Peran NPL Terhadap Hubungan Antara LDR dan Kinerja Perusahaan (Study Empiris Pada Bank BUMN yang Terdaftar di BEI). 3(2), 45-56.

Sucipto, D. J. J. A. U. S. U. (2003). Penilaian Kinerja Keuangan.

Sukma, Y. L. J. J. A. (2013). Pengaruh Dana Pihak Ketiga, Kecukupan Modal dan Risiko Kredit terhadap Profitabilitas (Perusahaan Perbankan yang Terdaftar di BEI). 1(2). 
Syarif, S. (2006). Analisis Pengaruh Rasio-Rasio Camels Terhadap Net Interest Margin (Study Empiris Pada Bank-bank yang Listed di Bursa Efek Jakarta Periode Tahun 2001-2004). program Pascasarjana Universitas Diponegoro,

Tamtomo, H. S., Hersugondo, H. J. S. J. o. A., \& Banking. (2012). Pengaruh CAR, NPL, DPK dan ROA Terhadap LDR Perusahaan Perbankan Indonesia. 1(1).

Taswan, C., \& Si, M. J. Y. U. S. Y. Y. (2010). Manajemen Perbankan.

www.bankmandiri.co.id.

www.bni.co.id.

www.bri.co.id.

www.btn.co.id. 